\title{
Historical Tragedy and the End of Christian Humanism: Nicolaus Vernulaeus (1583-1649)
}

\author{
James A. Parente, Jr.
}

In 1656 the highly esteemed rector magnificus of the University of Louvain, Franciscus de Baillencourt, who was serving his fourth term in that office, was feted by his colleagues in anticipation of his departure for his new position as consiliarius of the Council of Mechelen. Baillencourt had spent his entire academic life at Louvain, from his student years in the 1620 s and professorship in civil and canon law to his thirteen-year service as praeses of the Collegium Winckelianum (Wenkelem). As befitted such a long-standing colleague, he was presented with several gifts marking his career transition. Among the many tokens of appreciation that he received was a two-volume edition of the fourteen tragedies of the late Louvain professor of rhetoric and imperial Habsburg historiographer Nicolaus Vernulaeus, which was presented to him by the local printers Petrus Sassenus and Hieronymus Nempaeus. The printers deemed this gift especially appropriate, for Vernulaeus had also served as the university's rector, written its first history, and contributed greatly, as Baillencourt had done, to maintaining the distinguished academic reputation of the university for educating the Catholic nobility of Europe. But this particular gift suggested an even closer tie between the two rectors. Vernulaeus's plays were much more than the usual academic dramas that were produced in Catholic Europe by teachers of rhetoric to strengthen the faith of their students. In contrast to the largely biblical and hagiographic subjects favored by late sixteenth- and early seventeenth-century school dramatists, Vernulaeus's writing was deeply grounded in history, especially medieval and contemporary history, and in the Catholic conception of the state and the ideal Christianus politicus. No gift was more suitable for the talented and administratively able Baillencourt than these dramatic exempla of the challenges of holding high political office in the mid-seventeenth century. ${ }^{1}$

1 Nicolaus Vernulaeus, Tragoediae in duos tomos distributae, editio II (Lovanii: typis Petri Sasseni et Hieronymi Nempaei, 1656 ), sig. ${ }^{*} 2{ }^{*}{ }_{4}$. Franciscus de Baillencourt (1610-1681) continued his illustrious career at Mechelen ascending there to the position of Vicar General; in 1670 he was appointed Bishop of Bruges.

(C) JAMES A. PARENTE, JR., 2016 | DOI: 10.1163/9789004323421_007 
The turn to history and the proliferation of historical subjects in neo-Latin theater has generally received much less attention than the treatment of history in contemporary vernacular drama. Most recent discussions of early modern historical drama avoid neo-Latin theater altogether or discuss it only cursorily in order to move on to the grander and more complex vernacular plays of Shakespeare, Pierre Corneille, Andreas Gryphius or P.C. Hooft. ${ }^{2}$ Such haste may be due, in part, to an eagerness to regard Latin theater as a preliminary rather than contemporary stage in the development of European drama from religious theater to secularized drama. More likely, the tendency of neo-Latin school playwrights to conceptualize history sub specie aeternitatis and to represent past events as the demonstration of God's Providential working in the world and the ultimate triumph of Divine Justice may have further contributed to the dismissal of historical theater in Latin as naïve and predictable. An investigation of the tragedies of Vernulaeus, however, complicates this simplistic understanding of historical representation, provides an opportunity to connect his theatrical praxis with contemporary historical events and political theory, and adumbrates the links between tragedy and history that underlie both neoLatin and vernacular Baroque theater.

Despite the stature that Vernulaeus held among his learned contemporaries, his works have received relatively scant attention. ${ }^{3}$ Since most Netherlandic

2 See, for example, Herbert Lindenberger, Historical Drama: The Relation of Literature and Reality (Chicago: University of Chicago Press, 1975); Matthew H. Wikander, The Play or Truth and State: Historical Drama from Shakespeare to Brecht (Baltimore: The Johns Hopkins University Press, 1986). More recently Dirk Niefanger has viewed neo-Latin historical drama alongside vernacular plays, but only for the sixteenth and early seventeenth centuries: Dirk Niefanger, Geschichtsdrama der frühen Neuzeit 1495-1773 (Tübingen: Niemeyer, 2005).

3 Three of Vernulaeus's plays have been printed in modern editions and translated. The Wallenstein tragedy Fritlandus has been edited twice: Johannes Bolte (ed.), Coligny, Gustav Adolf, Wallenstein: Drei zeitgenössische lateinische Dramen von Rhodius, Narssius, Vernulaeus (Leipzig: Hiersemann, 1933) Bibliothek des litterarischen Vereins, Sitz Tübingen, 280, and Jean-Marie Rousseau and Henri Plard (eds. and transl.), Un 'Wallenstein' néolatin: 'Le Duc de Friedland', 'Fritlandus tragoedia' (1637) par Nicolaus Vernulaeus (Nicolas de Vernulz) (Brussels: University Press, 1989). See also Antoine de Latour (ed. and transl.), Jeanne d'Arc, tragédie latine par Nicolas de Vernulz, édition nouvelle (Orléans: H. Herluison, 1880); Louis A. Schuster (ed. and transl.), Henry viII: A Neo-Latin Drama by Nicolaus Vernulaeus (Austin: University of Texas Press, 1964). Beyond the prefatory materials in these editions, there have only been a few studies of Vernulaeus's plays. See: Ton Harmsen, 'Conradinus en de trits Vernulaeus, Oudaan, Smids', in Bert van Selm (ed.), De letter doet de geest leven: Bundel opstellen aangeboden aan Max de Haan (Leiden: Publikaties van de vakgroep Nederlandse taal- en letterkunde, 1980), pp. 172-189, and B.A. Vermaseren, 'Een onbekend drama over de H.H. martelaren van Gor- 
Latin dramas after 1550 were produced in the Southern Netherlands by Catholic authors, there has been little incentive for literary historians fixated on the Protestant North to explore the extensive repertoire of Jesuit and Augustinian drama in Flanders, Hainaut, Artois, Brabant, and the bishopric of Liège. The literary historian Gerardus Knuvelder remarked, for example, that both Latin and vernacular drama in the Southern Netherlands was too traditional (i.e., medieval and religious) and unoriginal after 1600 to be of any importance. ${ }^{4}$ More progressive literary-historical surveys such as Maria Schenkeveld's Dutch Literature in the Age of Rembrandt (1991) and her magnificent Nederlandse literatuur: Een geschiedenis (1994) hardly mention neo-Latin theater, and for that matter any seventeenth-century writers of the Southern Netherlands, in the vernacular or Latin, save for Michiel de Swaen. ${ }^{5}$ More recently, Karel Porteman and Mieke Smits-Veldt have examined Latin writing alongside vernacular texts, and Jan Bloemendal has explored the elaborate interplay between Latin and vernacular drama, but there is still much work to do in analyzing and assessing these two traditions. ${ }^{6}$ The wide range of dramatic subjects presented

cum', Bijdragen voor de geschiedenis van de Provincie der Minderbroeders in de Nederlanden 7 (1951), 25-38; Elisabeth Klecker, 'König Ottokars Glück und Ende in lateinischer Sprache: Nicolaus Vernulaeus, Ottocarus Bohemiae Rex', Jahrbuch der Grillparzer Gesellschaft 3. Folge, Bd. 21 (2003-2006), 65-107.

4 Gerard P.M. Knuvelder, Beknopt handboek tot de geschiedenis der Nederlandse letterkunde ('sHertogenbosch: Malmberg, 1952), p. 226.

5 Maria A. Schenkeveld, Dutch Literature in the Age of Rembrandt: Themes and Ideas (Amsterdam and Philadelphia: John Benjamins, 1991). Schenkeveld mentions Vondel's translation of Hugo Grotius's Sophompaneas (p. 53) and Daniel Heinsius's commentary on Aristotle's Poetics, De tragoediae constitutione (p. 151). See also M.A. Schenkeveld-van der Dussen et al. (eds.), Nederlandse literatuur: Een geschiedenis (Groningen: Martinus Nijhoff, 1993), pp. 303-308.

6 Karel Porteman and Mieke Smits-Veldt, Een nieuwe vaderland voor de muzen: Geschiedenis van de Nederlandse literatuur, 1560-1700 (Amsterdam: Bert Bakker, 2008). Porteman and SmitsVeldt emphasize the contemporary Dutch translations of neo-Latin works, e.g., the discussion of Daniel Heinsius's plays, pp. 172-179. For a fuller examination of the many connections between vernacular and neo-Latin drama in the Netherlands, see Jan Bloemendal, 'Transfer and Integration of Latin and Vernacular Drama in the Early Modern Period: The Case of Everyman, Elckerlijk, Homulus and Hecastus', Arcadia 44 (2009), 274-288; Jan Bloemendal, 'Similarities, Dissimilarities, and Possible Relations between Early Modern Latin Drama and Drama in the Vernacular', in Philip Ford and Andrew Taylor (eds.), The Early Modern Cultures of Neo-Latin Drama (Louvain: Leuven University Press, 2013), pp. 141-157, and Jan Bloemendal, 'Neo-Latin Drama in the Low Countries', in Jan Bloemendal and Howard B. Norland (eds.), Neo-Latin Drama in Early Modern Europe (Leiden and Boston: Brill, 2013) Drama and Theatre in Early Modern Europe, 3, pp. 293-364. 
by South Netherlandic Catholic writers during this period, from the CounterReformation polemics of Andreas Fabricius to the tragedies of Vernulaeus, and the elevated Latin style of seventeenth-century Augustinians such as Johannes Chrysostomus Loots and Emmanuel Rodriguez attest, however, to the lively productivity of these playwrights. ${ }^{7}$

Such neglect is indeed a pity, for Vernulaeus is a figure whose works and career must be seen against the larger canvas of seventeenth-century European history. Vernulaeus had come of age during a period of renewed Catholic devotion, whose intensity increased with the progress of the Dutch Revolt (Eighty Years' War). Born in Roblemont in the Duchy of Luxembourg in 1583, he studied at two institutions of Counter-Reformation fervor: the Jesuit school in Trier, where he may have first seen and, as a student, performed in the humanist religious plays of that school, and the University of Cologne, a city where the Jesuits also sustained an active school theater repertoire. In 1608, he was called to the University of Louvain as instructor in rhetoric, and two years later in 1610, he was appointed public orator (Rhetor publicus) and professor of eloquence in the Collège de Porc, an appointment finally confirmed by the Faculty of Arts in 1617. Vernulaeus remained at Louvain until his death in 1649 during which time he displayed an exceptional facility for publishing and a remarkable scholarly range even by prolix early modern standards. Besides his fourteen tragedies, he authored large tomes on political and economic theory, moral philosophy, contemporary history, and current religious issues. He pandered to the Habsburg regents in the Southern Netherlands, Albrecht and Isabella, as well as to their distant relatives in Vienna with embarrassing panegyrics of their militaristic, imperialist policies, and his loyalty was eventually rewarded with a position as Royal Historiographer to the Holy Roman Emperor Ferdinand III in 1646. He also edited and published several volumes of public orations by his students in order to glorify his university and enhance its reputation as a center of Catholic thought. ${ }^{8}$

7 No studies have been undertaken of all the dramas of Andreas Fabricius (1520?-1581), whose plays were written while he was in service to Duke Albert v of Bavaria, nor of the two tragedies of the early seventeenth-century Augustinian Emmanuel Rodriguez. For his fellow Augustinian Joannes Chrysostomus Loots, see Paul van Peteghem, 'Joannes Chrysostomus Loots', Augustiniana 19 (1969), 552-582.

8 The most complete overview of Vernulaeus's life and works can be found in Joost Depuydt's unpublished licentiate thesis: Joost Depuydt, Nicolaus Vernulaeus (1583-1649): Een bio-bibliografische studie (Louvain: unpublished doctoral thesis, 1991). Much of the valuable information there can be found at Joost Depuydt, 'Nicolaus Vernulaeus', in Jan Bloemendal and Chris Heesakkers (eds.), Bio-bibliografie van Nederlandse humanisten, Digital edition Digitaal 
There are three aspects of Vernulaeus's writing that distinguish him from many other early modern Latin playwrights in the Low Countries. First, Vernulaeus was arguably the most prolific writer of historical drama in the early modern Netherlands. Eleven of the tragedies were published between 1610 and 1635; ten appeared together in a collected edition of his plays in 1631, and the widely disseminated two-volume 1656 collection that had been presented to Baillencourt contained fourteen dramas, two of which had never been printed before. In contrast to most sixteenth-century Latin school playwrights and to his Latinwriting contemporaries, Vernulaeus expanded the familiar repertoire of sacred theater to present topics from late antique, medieval, sixteenth-century, and even recent seventeenth-century history. In addition to tragedies on martyrs such as St. Eustachius (fl. second century AD), the sixth-century Spanish prince St. Hermenigildus, the seventh-century bishop St. Lambert of Maastricht, and the 1572 Dutch martyrs of Gorkum, Vernulaeus brought to the stage the hapless first son of Constantine the Great, Flavius Julius Crispus; the imperial usurper Maximianus (ca. 355-388AD); Theodoric the Ostrogoth; Thomas Becket and Henry II; the licentious eleventh-century Polish king, Boleslaus II; Conradin von Hohenstaufen; Jeanne D'Arc; Henry viII and Thomas More; Rudolf I Habsburg and his rival Ottokar of Bohemia; and the disloyal Habsburg general Wallenstein. In many instances, these figures remained the staple of CounterReformation playwrights, especially the Jesuits, throughout the seventeenthand early eighteenth-century in the Latin schools of Central and Eastern Europe. ${ }^{9}$ Secondly, Vernulaeus's dramatic writing was closely allied with his extensive historical, political, and moral-philosophical orations, treatises, and handbooks. Many Latin school playwrights had also composed non-dramatic works, usually related to their pedagogical tasks, such as commentaries on ancient writers, compendia of didactic aphorisms, public orations, and devotional handbooks, but such writings rarely related to their works for the school stage. Vernulaeus's dramatic compositions, however, offer literary historians a unique perspective on a humanist Latin writer in his study distilling his view of history and political action into theatrical representations. Thirdly, and most

Wetenschaphistorisch Centrum (Digital Web Center for the History of Science in the Low Countries) / Huygens Institute, KNAw, 2009: http://www.dwc.knaw.nl/.

9 For plays on similar topics in the German Empire, see Jean-Marie Valentin, Le théâtre des Jésuites dans les pays de langue allemande: Répertoire chronologique des pièces représentées et des documents conservés (1555-1773) (Stuttgart: Anton Hiersemann, 1983-1984) Hiersemanns Bibliographische Handbücher, 3.1 and 3.2. For the Low Countries, see L. van den Boogerd, Het Jezuietendrama in de Nederlanden (Groningen: J.B. Wolters, 1961), pp. 222-255. 
importantly, Vernulaeus's historical plays foreground an increasingly complex problem in the late humanist world: the relationship between idealized political behavior informed by Christian moral-philosophical principles, and expedient political action attuned to the acquisition and maintenance of power and authority during the religious wars of the seventeenth century.

\section{Tragedy and History: Tradition and Transformation}

Vernulaeus's turn to historical topics must be seen in the context of contemporary theatrical practice, the humanists' alignment of tragedy and history, and his increasing interest in academic theater as a site for political instruction. No early modern Latin playwright operated in an artistic vacuum: Vernulaeus's concept of theater, its pedagogical function and his choice of dramatic subject were shaped by humanist and vernacular traditions. Vernulaeus's view of drama as an literary genre can be gleaned from scattered statements throughout his writings, chiefly the dedicatory letters that accompanied his published plays and from a brief discussion of the state's role in sponsoring theater from his Institutionum politicarum libri IV (Political Instruction in Four Books, 1623). To be sure, many learned contemporaries praised Vernulaeus's dramas in the liminary poems that accompanied his plays. With customary hyperbole, he was variously hailed as a new Aeschylus or Euripides, and as a model for Latin tragedy in the tradition of Seneca:

Si quis Tragoediam nosse, si quis Senecam

Velit exhiberi, vel vetustorum stylum:

Dramata theatris Vernulaeus sat dabit

Gravitate, claritate concinna admodum

Quae varia dubiae fata fortunae notent. ${ }^{10}$

(If anyone should wish to learn about tragedy,

Or to see Seneca or the style of the ancients on display,

Vernulaeus will guarantee theaters dramas

That show a variety of stories of ever-changing Fortuna

With gravity and exceptionally elegant clarity.)

$10 \quad$ Nicolaus Vernulaeus, Divus Eustachius sive fidei et patientiae triumphus, tragoedia (Louvanii: typis Philippi Dormalii, 1612), p. 8. See also Vernulaeus, Tragoediae (1656), sig. *5. 
Vernulaeus's style was repeatedly singled out for its elegance, and his dramatic subjects for their piety and utility in educating youth who would one day assume positions of power in society. Such a lofty purpose was advocated by Vernulaeus in his Institutionum politicarum libri $I V$, where, echoing the established Christian humanist practice of emending pagan theater, he criticized the raciness and frivolity of public plays focused on the erotic adventures and sexual violence perpetrated by libidinous youths. Instead, he admonished the state to oversee theatrical performances and to ensure that the young male performers would be instructed in virtue and piety, the traditional goals of earlier Christian drama, and in civic prudence ('civilis prudentia'), a new aspiration." In Vernulaeus's hands, academic theater became the locus for political instruction and historical tragedy its preferred medium.

Tragedy had long been associated with history. The fourth-century grammarian Aelius Donatus had made history a defining characteristic of tragedy. ${ }^{12}$ Whereas comedy represented everyday fictive events through characters of middling social status, tragedy was often grounded in history, and reserved for the highest ranking members of society and their calamitous end. Since the fourteenth century, humanist commentators on the tragedies of Seneca, such as Albertino Mussato of Padua, repeatedly underscored the political function of tragedy: tragedies, by definition, deal with the downfall of kings or great historical personages, and as fifteenth- and sixteenth-century commentators argued, tragedies were ideally suited for the dispensation of moral counsel of use to princes. ${ }^{13}$ In 1576 , for example, the Frisian lawyer-humanist, Georgius

11 Nicolaus Vernulaeus, Institutionum politicarum libri quatuor (Lovanii: typis Philippi Dormalii, 1623), pp. 488-489.

12 Aelius Donatus, Commentum Terenti (Leipzig: B. Teubner, 1902-1908), pp. 2-3.

13 On the political messages inscribed in early humanist tragedy, see Hartmut Beyer, Das politische Drama im Italien des 14. und 15. Jahrhunderts: Humanistische Tragödien in ihrem literarischen und funktionalen Kontext (Münster: Rhema, 2008), esp. pp. 89-103 on Mussato. The widely circulated 1514 Badius edition of Seneca's tragedies contains prefatory remarks by Badius, Gellius Bernardinus Marmita, Danielis Gaietanus, and Benedictus Philologus in which such sentiments were espoused. L. Annei Senecae Tragoediae pristinae integritati restitutae per exactissimi iudicii viros ... explanate diligentissime tribus commentariis G. Bernardino Marmita Parmiensi, Daniele Gaietano Cremonensi, Iodoco Badio Ascensio [Paris], 1514. Marmita remarks that the utility of tragedy lies in the elegance and richness of its language, and the knowledge that it provides about the mutability of fortune and the attainment of a virtuous life: 'Ex tragoediis utilitas multifariam habetur: carminis nitor elegans et venusta dicendi copia, cognitio rerum varia ut homines intelligant fortunam esse mutabilem et illius levitati non esse fidendum, solamque virtutem esse colendam et ad beatam vitam properandum' (sig. Aaiiiiv). 
Ratallerus, confessed that the main impetus for his translation of the tragedies of Sophocles and Euripides into Latin was to publicize the practical advice their works contained on morality, government, and the maintenance of civil harmony. ${ }^{14}$

Historical topics had occasionally served as the subject of neo-Latin tragedy, especially plays fashioned after the model of the historical drama Octavia that Renaissance humanists attributed to Seneca. Mussato composed his Ecerinis (ca. 1314) on the career of the notorious tyrant Ezzelino III da Romano after the Senecan model, and as Hartmut Beyer has recently shown, neo-Latin Italian tragedy in the later Trecento and Quattrocento, frequently imparted a political message through mythological or ancient historical subjects. ${ }^{15}$ In the transalpine world, the Bavarian poeta laureatus Jacob Locher, who studied humanist drama during his Italian sojourn and subsequently edited the Octavia along with two other Senecan plays, chronicled the disastrous 1494 Italian campaign of Charles VIII against Neapolitan Aragon in his Historia de rege Franciae (History of the King of France, 1495), which, though written in prose, betrayed traces of his familiarity with the language and structure of Senecan drama. His second historical tragedy, Tragoedia de Thurcis et Suldano (Tragedy concerning the Turks and the Sultan, 1497), inspired by Carlo Verardi's (1492) Historia Baetica, a triumphalist representation of the Spanish reconquest of Granada, exhorted the Emperor Maximilian I to launch a crusade against the marauding Turks by representing an imagined triumph of Habsburg over the sultan. ${ }^{16}$ Sixteenth-century German humanists such as Henricus Schottenius and Nicodemus Frischlin likewise introduced medieval and recent historical events to the neo-Latin stage, while their vernacular contemporaries Hans Sachs and Jacob Ayrer used historical subjects to praise or disparage political behavior. ${ }^{17}$ The prolific Bavarian biblical playwright Hieronymus Ziegler and dramatists from the Strasbourg academy also turned to subjects from ancient history, chiefly Herodotus, to vary their repertoire, and Italian and German Jesuits such as Bernardino Stefonio and Jacob Bidermann mined the annals

14 'ad vitam recté instituendam, moresque formandos, tum ad Rempublicam bene gubernandum exempla depromant principes et magistratus'. Georgius Ratallerus, Tragoediae Sophoclis quotquot extant carmine latino redditae (Antverpiae: ex officina Georgii Silvii, 1570), sig." $2^{\mathrm{v}-{ }^{*}} 3$.

15 Beyer, Das politische Drama im Italien, pp. 33-314.

16 Cora Dietl, Die Dramen Jacob Lochers und die frühe Humanistenbühne im süddeutschen Raum (Berlin and New York: Walter de Gruyter, 2005) Quellen und Forschungen zur Literatur- und Kulturgeschichte, 37 (271), pp. 63-135.

17 Niefanger, Geschichtsdrama der Frühen Neuzeit, pp. 65-112. 
of late antiquity to explore the moral dilemmas afflicting protagonists constrained to choose between personal ambition and virtue. ${ }^{18}$ In 1594, Georg Calaminus, a professor at the gymnasium in Linz, published an exceptionally erudite school play on the thirteenth-century ruler Rudolf of Habsburg, for which he was crowned poet laureate in Vienna, where, unfortunately, he contracted scarlet fever and died upon his return to his relatively hygienic hometown. ${ }^{19}$

The frequency of historical topics drawn from secular ancient, medieval, or early modern history on the neo-Latin stage increased markedly after 1600 and in Jesuit hands, gradually overshadowed tragedies based on the Bible. ${ }^{20}$ To be sure, many biblical topics could also be construed as historical (consider, for example, the many plays about King Saul in the vernacular and Latin from the 1580 s and 1590s), and many hagiographical subjects such as the martyrdom of St. Catherine of Alexandria or St. Eustachius, both popular sixteenth-century topics, contain elements from late antique history. These biblical and hagiographical subjects frequently had a more secular intention-a lesson in the art of government, for example- than a moral-philosophical or religious purpose: one thinks here of the tragedies of the late French humanists Jean de la Taille and Robert Garnier in this regard, as well as many of the biblical tragedies

18 Hieronymus Ziegler argues for the utility of historical knowledge for future political leaders: Hieronymous Ziegler, Cyrus Major: Drama tragicum (Augustae: Philippus Ulhardus, 1540), sig. A3-A4. For the politicization of Strasbourg school drama, see: James A. Parente, Jr., 'Tragoedia Politica: Strasbourg School Drama and the Early Modern State, 1583-1621', Colloquia Germanica 29/1 (1996), 1-11. Bernardino Stefonio's widely disseminated tragedy Crispus (1597) explored the moral dilemma confronting the eponymous hero when his stepmother Fausta attempted to seduce him. See the introduction by Lucia Strappini to her modern edition and translation: Bernardino Stefonio, Crispus (Rome: Bulzoni, 1998), Bibliotheca di cultura, 556, pp. i-xxvii. Jacob Bidermann's Belisarius (1607; published posthumously in 1666) delineates the moral rehabilitation of the protagonist after his fall from favor as the Emperor Justinian's leading general. Extensive commentary to Bidermann's work is provided by Harald Burger in his edition: Jakob Bidermanns 'Belisarius': Edition und Versuch einer Deutung (Berlin: Walter de Gruyter, 1966).

19 Georg Calaminus's plays have been edited, translated, and extensively commented on by Robert Hinterndorfer. See Georg Calaminus, Sämtliche Werke, ed. Robert Hinterndorfer (Vienna: Edition Praesens, 1998), vol. 2 (plays and translation); vol. 3 (commentary); vol. 4 (Calaminus's life and works) Wiener Neudrucke, 13-15. For an analysis of Calaminus's Rudolphottocarus compared to Vernulaeus and Franz Grillparzer's nineteenth-century tragedy, see Klecker, 'König Ottokars Glück und Ende in lateinischer Sprache', pp. 67-96. Elida Maria Szarota, Geschichte, Politik und Gesellschaft im Drama des 17. Jahrhunderts (Berne: Francke, 1976), pp. 7-62. 
of Vondel. ${ }^{21}$ But even within such intersections between temporal and spiritual subjects, Vernulaeus's works are distinctive because of his extensive use of secular historical topics. His historical tragedies do not simply commemorate an unjustly slain hero, or transmit moral lessons through the punishment of morally deviant rulers, but provide political instruction for future statesmen weighing practical and expedient choices in a morally complex world.

In the Low Countries, the 1580 s and 1590 s witnessed an efflorescence of historical topics, especially those drawn from very recent history, on the vernacular and neo-Latin stage. Consider, for example, the 1593 tragedy Maria Stuarta by Adrianus Roulerius of Douai, the epicenter of the Catholic resistance to England; the tragedies on the murder of William of Orange by Caspar Casparius and Daniel Heinsius (Auriacus, 1602), a threnody for the loss of this great Protestant leader, and taking the Catholic side, the Latin poet, Panagius Salius (Nassovius, 1589), in which the assassin Balthasar Gerard is regarded as a savior of the Netherlands. ${ }^{22}$ In the early seventeenth-century, P.C. Hooft contributed to the creation of early modern Dutch national identity in his Baeto (1626), and to a lesser extent, in his earlier Geeraerdtvan Velsen (1613), while the poet Jacob Zevecotius idealized the Dutch triumph over the Spaniards before Leiden in his Het belegh van Leyden (The Siege of Leiden, 1626) and the happy sequel, Het ontzet van Leyden (The Relief of Leiden, 1630), victories which Zevecotius, a former Augustinian priest and Latin school playwright from Brabant, extolled with the zeal of a patriotic Protestant convert. ${ }^{23}$ Historical topics were

21 On the political significance of Robert Garnier's biblical tragedies, see Gillian Jondorf, Robert Garnier and the Themes of Political Tragedy in the Sixteenth Century (London and Cambridge: Cambridge University Press, 1969). On tragedy and politics in Jean de la Taille, see Eugenio Refini, “"Profiter de quelque chose à ma république”: Poetica e politica nell'epistola De l'art de la tragédie di Jean de la Taille', Studi Francesi 52 (2009), 234-250. The political arguments underlying Vondel's dramas, both religious and secular, have been most recently examined by Frans-Willem Korsten, Vondel belicht: Voorstellingen van soevereiniteit (Hilversum: Verloren, 2006) [= id., Sovereignty as Inviolability: Vondel's Theatrical Explorations in the Dutch Republic (Hilversum: Verloren, 2009)].

22 Daniel Heinsius, Auriacus sive libertas saucia, ed. Jan Bloemendal (Voorthuizen: Florivallis, 1997), Doctoral thesis, Utrecht, 2 vols. On Heinsius's Auriacus, see most recently Juliette A. Groenland, 'The Deadly Earnest of History Plays', in Bloemendal and Ford, Neo-Latin Drama: Form, Functions, Receptions, pp. 23-33. On Casparius, see Juliette A. Groenland, “"Toneel als pamflet"? De Princeps Auriacus sive libertas defensa (1599) van Caspar Ens', De zeventiende eeuw 25 (2009), 26-38.

23 Heinsius's Auriacus inspired several vernacular Dutch historical dramas: see Juliette A. Groenland, 'Predicting the Present: Final Prophesies in Latin and Dutch History Plays', in Christel Meier, Bart A.M. Ramakers and Hartmut Beyer (eds.), Akteure und Aktionen: Fi- 
also popular in the Rederijker chambers in the early seventeenth-century: there were Seneca-inspired tragedies about the assassination of William of Orange by Jacob Duym and Gijsbreght van Hogendorp, following Heinsius's example, and the 1610 tragicomedy on the assassination of King Henri IV of France by Abraham de Koningh, a Rederijker of the Brabantine chamber in Amsterdam. ${ }^{24}$ Humanist playwrights, and Rederijker writers inspired by humanist drama, used the stage to debate political issues, such as the legality of the Dutch Revolt and the legitimacy of the assassination of William of Orange, or the role of religion in the political order, as they assembled a cadre of Dutch and/or historical heroes for their audience to emulate.

Vernulaeus's historical subjects were carefully chosen as a Catholic replique to this generally Protestant appropriation of the past. Only two of his plays betray a specifically Netherlandic context: his first tragedy from 1609 (printed 1610), Gorcomienses, on the 1572 martyrdom of nineteen Dutch Catholics at Brielle, and his later Lambertus (first published in the collected edition of his plays in 1656), on the martyrdom of St. Lambert, a topic honoring a patron saint of that hotbed of Counter-Reformation sentiment, the bishopric of Liège. ${ }^{25}$ For the most part, Vernulaeus's remaining subjects were drawn from German, English, French, and Polish medieval and early modern history: this topical range typified both the universalizing tendency of the Counter-Reformation to identify supra-national, supra-ethnic heroes, a practice canonized by later seventeenth-century Jesuit playwrights, and at the same time to honor the

guren und Handlungstypen im Drama der Frühen Neuzeit (Münster: Rhema, 2008), pp. 461483. For later vernacular Dutch historical tragedies, see Henk Duits, Van Bartholomeusnacht tot Bataafse opstand: Studies over de relatie tussen politiek en toneel in het midden van de zeventiende eeuw (Hilversum: Verloren, 1990).

24 Jan Bloemendal addresses the relationship between Heinsius's Auriacus and Gijsbreght van Hogendorp in his 1997 edition and study of Heinsius's play (n. 22). He also compares Casparius's and Heinsius's tragedies with vernacular Dutch dramatizations of Duym and van Hogendorp in: Jan Bloemendal, 'De dramatische moord op de Vader des Vaderlands: De verhouding tussen vier typen toneel in de vroegmoderne Nederlanden', De zeventiende eeuw 23 (2007), 99-117. For other vernacular connections to Heinsius, see Juliette A. Groenland, 'Playing to the Public, Playing with Opinion: Latin and Vernacular Dutch History Drama by Heinsius and Duym', in Jan Bloemendal, Arjan van Dixhoorn and Elsa Strietman (eds.), Literary Cultures and Public Opinion in the Low Countries, 1450-1650 (Leiden and Boston: Brill, 2011) Brill's Studies in Intellectual History, 197, pp. 121-150. On Zevecotius's plays about the siege of Leiden, see Bettina Noak, Politische Auffassungen im niederländischen Drama des 17. Jahrhunderts (Münster: Waxmann, 2002), pp. 85-100.

25 Gorcomienses sive fidei exilium (Coloniae: sumptibus Bernardi Gualteri, 1610). For Lambertus, see Vernulaeus, Tragoediae, 1656, pp. 856-903. 
multi-national student clientele from Catholic Europe that populated Vernulaeus's college.

At first glance the unusual size and topical variety of Vernulaeus's tragedies appear to suggest a marked break from contemporary practice, but in fact, his choice of subject reflects his sensitivity to the new work being produced elsewhere, and to the changing historical events that were unfolding in the German Empire and the Netherlands especially after the expiration of the Twelve Years' Truce in 1620. The early hagiographical play on St. Eustachius (1612), the patron saint of hunters, whose conversion to Christianity was effected by the appearance of the crucifix in the antlers of a stag he was pursuing, was very popular among Jesuit school playwrights in Austria, Bavaria and the Rhineland in the late sixteenth and early seventeenth centuries. ${ }^{26}$ The legend of St. Eustachius, which was typically set during the time of Emperor Trajan, provided an extensive narrative, reminiscent of Hellenistic romance, of the titular hero's fall from prosperity as a Roman tribune, the loss of his wife and children, his miraculous conversion to Christianity, and eventual reunion with his newly converted Christian family and their courageous martyrdom. The vicissitudes of fortune so fundamental to Senecan tragedy were on elaborate and frequent display throughout this early work.

Vernulaeus was also attuned to the neo-Latin Netherlandic tradition of Senecan tragedy. His posthumously published play on St. Lambertus, who was martyred by the seventh-century Frankish ruler Pepin of Herstal for refusing to acknowledge his concubine as his preferred partner, had also been treated in 1550 s by the Liège neo-Latin playwright Gregorius Holonius as a CounterReformation warning against clerical concubinage. Although Holonius and Vernulaeus both employed the language of Senecan tragedy in their dramas, Vernulaeus's treatment contains few traces of Holonius's earlier work, and concentrates more on the failings of Pepin as an effective ruler than on the glorious martyrdom of St. Lambert. ${ }^{27}$

26 Between 1584 and 1615, St. Eustachius plays were performed in Vienna (1584), Pruntrut (1593), Graz (1594; ca. 160o), Prague (1600), Augsburg (1603), Mainz (1603), and Innsbruck (1613). See Valentin, Le théâtre des Jésuites: Répertoire, pp. 24; 39; 40; 50; 56; 58; 77. Jesuit performances of St. Eustachius plays are recorded also for Ghent (1629) and Mechelen (1636). See van den Boogerd, Het Jezuietendrama in de Nederlanden, p. 238, and Raymond van Aerde, Het schooldrama bij de Jezuieten: Bijdrage tot de geschiedenis van het tooneel te Mechelen (Mechelen: H. Dierickx-Beke, 1937), pp. 70-71.

27 Gregorius Holonius, Lambertias (Antverpiae apud Ioannem Bellerum, 1556). On Holonius see:James A. Parente, Jr. 'Counter-Reformation Polemic and Senecan Tragedy: The Dramas of Gregorius Holonius (1531?-1594)', Humanistica Lovaniensia 30 (1981), 156-180. 
Vernulaeus's increasing interest in political questions also informed his adaptation of recent works from both Italian and French Jesuit drama. In 1628, he published a tragedy on Crispus, the son of the Emperor Constantine who falls prey to the unbridled passion of his lascivious stepmother. Vernulaeus may well have been drawn to this topic because of the renown attached to the popular Crispus (1597; printed 1601) of the Italian Jesuit Bernardino Stefonio, and to Stefonio's attempt to outdo Seneca's rendering of the similarly ill-fated love of Phaedra for her stepson in his Hippolytus. Stefonio's tragedy also had the unusual distinction of being reprinted several times in Italy, France, and in Antwerp, and was more widely disseminated than many Jesuit plays. ${ }^{28} \mathrm{In}$ the hands of the Jesuit, Crispus inhabits a loftier exemplary state as a Christian replique to the pagan characters ('superior in the sanctity of his behavior, his actions, and his contempt for death', 'sanctitate morum, rebus gestis, et mortis contemptione superior'). ${ }^{29}$ Vernulaeus likewise shares Stefonio's shift of emphasis away from the tormented pangs of the unrequited love of Constantine's wife Fausta that characterized Seneca's treatment of the material, but he also expands the role of Constantine to underscore the perils of kingship and the disastrous consequences of allowing passion to determine his actions, and the personal and political loss of his son who is also a loyal, humble, and talented military leader.

There are even closer ties between Vernulaeus's Theodoricus (1623) and Hermenigildus (published in 1656 but most likely written much earlier) and the similarly named plays by the French Jesuit Nicolas Caussin $\left(1583^{-1651)}\right.$, who had written these works as professor of rhetoric at the Collège de Henri IV (La Flèche) and the Collège de Clermont (Paris) in the late $1610{ }^{30}{ }^{30}$ Both dramas, which were published in 1620 , along with three other tragoediae sacrae

28 The editio princeps was printed in Rome, 1601 by Carolus Vullietus. For manuscript and printing history, see Stefonio, Crispus, ed. Lucia Strappini, pp. xli-xliii. The first Antwerp edition of Crispus was published in 1609 by Joachim Trogaesius; the play was reprinted in Antwerp in an anthology of French, Italian, and Flemish Jesuit drama: Selectae Patrorum Societatis Iesu tragoediae (Antverpiae: apud Ioannem Cnobbarum, 1634), vol. 1. Stefonio, Crispus, p. 17.

30 Nicolas Caussin, Tragoediae sacrae (Parisiis: ex officina Nivelliana, apud Sebastianum Cramoisy, 1620). George Hocking first noticed the connection to Vernulaeus's Theodoricus in his A Study of the 'Tragoediae Sacrae' of Father Caussin (1583-1651) (Baltimore: Johns Hopkins University Press, 1943), pp. 42-43. Caussin's dramas have been the subject of several recent studies: on Theodoricus see Jean-Frédéric Chevalier, 'Nicolas Caussin, héritier Sénèque et de Boéce dans Theodoricus', in Sophie Conte (ed.), Nicolas Caussin: Rhétorique et spiritualité à l'époque de Louis XIII: Actes du colloque de Troyes (16-17 septembre 2004) (Berlin: Lit, 2007) Ars Rhetorica, 19, pp. 79-102. 
of Caussin, were drawn from historical material representing the late antique conflict between Christian orthodoxy and Arianism - a clear parallel to the contemporary controversy between the Protestants and the Catholics in both the Low Countries and the German Empire. Given their easy adaptability for confessional polemic, it is not surprising that the Theodoricus and Hermenigildus material was especially popular among Jesuit playwrights in the German Empire, many of whom reworked Caussin's Hermenigildus though not in the same way as Vernulaeus. ${ }^{31}$ In Theodoricus, the eponymous sixthcentury Ostrogothic ruler, pursued the orthodox philosopher Boethius and his son-in-law the historian Symmachus and eventually had them executed for refusing to embrace Arianism. In Hermenigildus, the titular hero, the son of the sixth-century Spanish Visigothic king Levigildus, a staunch Arian, converts to Catholicism, fails to overthrow his heretical father, and is eventually condemned to death for refusing to abjure his new-found faith.

There are clear verbal and structural parallels between these two works of Caussin and those of Vernulaeus, but there are marked differences that give a broader indication of his evolving ideas about the political function of tragedy. In contrast to Caussin, Vernulaeus develops the historical material with an eye to both its religious and political message, for in his view, in the early modern confessionalized state, it was not possible, nor was it desirable, to separate ecclesiastical from political matters. The Theodoricus, for example, was expressly conceived as a study into the failings of kingship that can befall any monarch rather than as a partisan condemnation of an unrepentant heretic.

Vernulaeus's adaptation of the Theodoricus material for political instruction is further underscored by his introduction of the senex (old man), who functions variously as a commentator, chorus, and narrator in this play and in all the tragedies to follow. The senex is invariably on hand in almost every scene observing the historical events and drawing the audience's attention to each episode's significance. As the plot alternates between moments of exultant military victory and disastrous defeat, the senex reminds the viewers of the mutability of fortune and the vanity of worldly glory. But beyond such Senecan commonplaces, the senex also directs the audience to look beneath the surface of the plot, and especially at the motives underlying a character's statements and behavior. Given his didactic role, the senex unsurprisingly voices a myriad of memorable sententiae for the students to absorb and recall later as necessary. He also participates or eavesdrops on every debate among court counselors, political rivals, and spouses, or serves as an alter ego to a soliloquizing 
prince struggling between obligation and desire, law and passion, heresy and orthodoxy. The presence of the senex ensured that the correct lessons would be learned by the young audiences, especially those lessons that would serve them well in their future careers as statesmen or ecclesiastical leaders and administrators. Because of the presence of the senex, Vernulaeus could take more chances with his protagonists than the French Jesuit, especially in the creation of more complex characters wrestling against themselves to choose wisely since the 'old man' was almost inevitably on hand to explain events that could potentially mislead or confuse his students.

The senex enabled Vernulaeus to complicate his characterization of Theodoricus, albeit to a limited degree. He took pains in the dedicatory letter not to condemn Theodoricus's excessive pride and proclivity to anger as the mere ragings of an obstreperous tyrant. He is well aware of the historical record in which Theodoricus, despite his allegiance to the Arian heresy, was widely regarded as an effective ruler: 'Pray, do not look down on or indeed despise the unfortunate king. While he lived-if you set aside his heretical beliefs—, he was beyond all human praise' ('Noli obsecro miserum Regem despicere ac fastidire. Cum viveret (si Arianum in eo haeresin excipias) supra humanum praeconium erat'). ${ }^{32}$ And indeed throughout the first three acts before Theodoricus falls irretrievably into unrestrained cruelty, he is repeatedly advised by the senex and his other counselors to adhere to the rule of law, to investigate the alleged crimes of Symmachus and Boethius, and to weigh carefully the apparent proofs of their complicity in a conspiracy to overthrow the state. But Theodoricus is possessed with unbridled ambition to attain ever higher levels of personal glory, and he becomes increasingly impatient with, and distrustful of, those who do not immediately accede to his desires. The alleged treachery of Boethius and Symmachus stokes his fundamental insecurity as a supreme ruler even further, and he orders their execution, but the fortitude that Boethius and Symmachus embody in the face of death immediately reassures the audience of the ultimate triumph of Divine Justice.

It is this confidence in the inevitable manifestation of Divine Justice that inspired Vernulaeus to dedicate this particular play to Georg Adam, Count of Martinitz (1602-1651), and in choosing this dedicatee, to establish new connections between his drama and the convulsive events of the Thirty Years' War. Like many humanists, Vernulaeus chose his dedicatees carefully in the quest for

32 Nicolaus Vernulaeus, Theodoricus tragoedia (Lovanii: typis Henrici Hastenii, 1623), p. 3. The Theodoricus had been presented by Vernulaeus's students in October, 1622, but it was not printed until the following year. 
public approbation, financial support, social advancement, or as was primarily the case for his dramas, the intended message of the play. The unabashedly doctrinaire Gorcomienses sive fidei exilium (The Martyrs of Gorkum or Faith Exiled, 1610) had been dedicated to the renowned Counter-Reformation Cistercian preacher Bernardus de Montgaillard (d. 1628), who at that time was dazzling nobility and commoners alike with his inspiring sermons at the court of Albrecht and Isabella. ${ }^{33}$ Vernulaeus's second play Divus Eustachius sive fidei et patientiae triumphus (St. Eustachius or the Triumph of Faith and Patience, 1612), arguably his least inspired work, was directed at Nicolas de Fanson, the abbot of the monastic community at St. Hubert from 1611-1652, in recognition of Nicolas's recent appointment as abbot and of the many parallels between the lives of St. Eustachius and St. Hubert, both of whom had converted to Christianity while hunting. ${ }^{34}$ But with his third play Theodoricus, published after an eleven year hiatus, Vernulaeus moved beyond admired regional leaders to address administrators whose careers were deeply connected to broader contemporary political events.

Georg Adam of Martinitz was praised by Vernulaeus for his virtue and assiduity in his studies, but his noble Bohemian heritage linked him to the recent unrest in Prague that had precipitated the first stage of the Thirty Years' War. ${ }^{35}$ Georg's father was Jaroslav Bořita of Martinitz (1582-1649), who was one of the four unfortunate ambassadors sent by the enervated Emperor Matthias in 1618 to install his cousin Ferdinand of Tyrol as the King of Bohemia. ${ }^{36}$ Jaroslav and his fellow emissaries were harshly interrogated by the Bohemian estates, and once the Bohemians confirmed that the Emperor had indeed closed their Assembly with no intention of restoring it, they summarily threw the ambassadors out the window. Jaroslav survived the fall, protected as Vernulaeus imagined, by his virtue, and poised for even greater honor and distinction. In fact, Jaroslav's survival and subsequent reinstatement in his office was considered an exemplum of Divine Providence, reassuring his readers - were any in need of reassurance - that God will always protect those who defend Roman Catholi$\mathrm{cism}$. The glorification of the martyred Boethius and Symmachus thus provided the historical precedent for this contemporary reenactment of the triumph of orthodoxy.

33 Jean François Foppens, Bibliotheca belgica sive virorum in Belgio vita scriptisque illustrium catalogus (Brussels: Petrus Foppens, 1737), pp. 136-137.

34 Vernulaeus, Divus Eustachius, p. 5.

35 Vernulaeus, Theodoricus, pp. 5-7.

36 On Martinitz, see Zdenek Hojda, 'Martinitz, Jaroslav Bořita Graf von', Neue deutsche Biographie, 16 (1990), 302-303. 
Vernulaeus's Hermenigildus, which was not published until the posthumous 1656 edition of his collected tragedies, provided yet another opportunity for the glorification of Catholicism in the face of heretical rage. ${ }^{37}$ Hermenigildus was deeply indebted to Caussin's re-conceptualization of the historical sources: both writers centered the drama around the tragic relationship between Hermenigildus and his Arian father Levigildus, who, though longing for a lasting reconciliation with his allegedly rebellious son, is manipulated by his wife's advisors into believing that Hermenigildus is indeed determined to overthrow him. The conflict between orthodoxy and heresy that enlivened the Theodoricus of both playwrights is now accorded a lesser role so that the court intrigues that entrap both Levigildus and his son can become more apparent. Vernulaeus in fact enlarges upon the political lessons that can be gleaned from Levigildus's blindness to his queen's machinations and introduces the senex to explicate Hermenigildus's journey from outlaw to loyal, though orthodox, son of his father, to eventual martyr for Rome. The commingling of religion and history and the primacy accorded the political lessons to be learned henceforth become the distinctive signature of Vernulaeus's approach to tragedy.

By the mid 1620s, through his reworking of Caussin's plays, Vernulaeus had reconceptualized tragedy as political theater. In the dedicatory letter to his Ottocarus (1626), he observed that tragedy 'clearly reveals the nature of human existence and vicissitudes of states' ('humanae vitae mores et Rerumpublicarum mutationes aperte explicat'). ${ }^{38}$ Mindful of his students, Vernulaeus ascribed a moral function to tragedy; through experiencing the unfolding of tragic events, the students were enjoined to learn which virtues to acquire in order to avoid disaster in their own lives as future statesmen: temperance, moderation, clemency, and above all, prudence. ${ }^{39}$ The centrality of civic prudence underlies Vernulaeus's embrace of history and provides an important link to his political writings. In the 1620 s, as he was transforming historical subjects into political set pieces, Vernulaeus was also compiling his lectures on history and statecraft into his Institutionum politicarum libri IV (1623), and it is to that work we must now turn for a deeper understanding of the political ideas that would animate his historical dramas.

37 Vernulaeus, Tragoediae (1656), pp. 904-968.

38 Nicolaus Vernulaeus, Ottocarus Bohemiae rex seu rebellio contra Rudolphum I imperatorum (Lovanii: typis Philippi Dormalii, 1626), sig.*2v.

39 '... mirum quantum legendis tragoediis afficiantur, cum se procul ab iis malis abesse animadvertunt quibus alios tantopere vexatos cognoscunt'. Vernulaeus, Ottocarus, sig. ${ }^{*}{ }^{-}$ ${ }^{*} 3^{\mathrm{v}}$. 


\section{The Political Origins of Vernulaeus's Tragedies}

In adopting historical narratives for political instruction, Vernulaeus created a pantheon of Counter-Reformation heroes to challenge the Protestant cause. As hostilities resumed with the expiration of the Twelve Years' Truce in the Low Countries and the expansion of the religious conflict first to Bohemia and then throughout the German Empire, his productivity on historical and political topics increased markedly. During the 1620 s and 1630s, alongside his dramatic writings, he penned treatises on the origins of the war in the Empire, and on the justice of the Catholic resistance to the new Dutch regime, a perspective reinforced by the many Catholic victories over the Protestant North at that time; he also published several embarrassingly obsequious histories and panegyrics of the Habsburgs. He spoke broadly about the unparalleled genius of the Spanish general Ambrogio Spinola, the virtues of the Archduchess Isabella, and the legitimacy of the Habsburg campaigns against the Protestant states in the German Empire. The political orations of his students also dealt with pressing contemporary issues such as the illegality of the Dutch revolt against Spain and the necessity for a single religion in a modern state. ${ }^{40}$ But Vernulaeus's interest in politics was much more profound than the ephemerality that his choice of oratorical subjects implies. As an avid student of late sixteenth-century and early seventeenth-century political theory, he developed his own concept of the ideal modern state and used his dramatic works to illustrate the validity of his political ideas by historical example.

Vernulaeus delineated his political views in his Institutiones politicae, which was intended as the first part of a trilogy of treatises on civic life (vita civilis) and politics, family and household affairs (oeconomia), and ethics (moralia), and he published separate volumes in each of these areas. ${ }^{41}$ The Institutionum

40 As an example of Vernulaeus's unreserved embrace of the Habsburgs as representatives of pietas Austriaca, see his Virtutum augustissimae gentis Austriacae libri tres (Lovanii: typis Iacobi Zegeri, 1640). For an historiographic analysis of these writings, see Veronika Coroleu Oberparleiter, 'Nicolaus Vernulaeus' Darstellung der Habsburger: Apologia, Virtutes und Historia Austriaca mit einem Exkurs über die Methodus legendi historias', Humanistica Lovaniensia 56 (2007), 233-270. A full listing of the range of Vernulaeus's political writings can be found in Depuydt, 'Nicolaus Vernulaeus' (n. 8). For a useful discussion of several of Vernulaeus's political orations, see Katharina Graupe, Oratio historica-Reden über Geschichte: Untersuchungen zur praktischen Rhetorik während des spanisch-niederländischen Konfliktes im 16.und 17. Jahrhundert (Berlin: De Gruyter, 2012), pp. 303-369.

41 Vernulaeus, Institutionum politicarum libri IV (n. 11); Institutionum moralium libri IV (Louvanii, typis Philip. Dormalii, 1625); Institutionum oeconomicarum libri II (Lovanii: typis 
moralium libri IV (1625) contains many passages about the affects-anger, avarice, lust, love, clemency — that reappear in Vernulaeus's dramatic characterizations, especially of rapacious tyrants, but his political handbook provides the best guide to understanding his historical plays. Here he set forth in detail his concept of the ideal Catholic state: a monarchy ruled by a prudent statesman who possesses the ability and power to maintain peace. No other aim was more fervently desired in the war-torn Netherlands of the 1620s, and Vernulaeus was quick to outline a political program on the best method to attain it.

The Institutiones politicae was heavily indebted to two contemporary schools: the practical Neo-Stoic political philosophy of Justus Lipsius and the recent Counter-Reformation revision of Lipsius by the German Jesuit Adam Contzen. Vernulaeus's treatise also revealed his extensive first-hand familiarity with many sixteenth-century political writers: Machiavelli; the Spanish scholastics Francisco de Vitoria (1483-1546) and Francisco Suárez (1548-1617), and Juan de Mariana whose handbook for princes, De rege et regis institutione (The King and the Education of the King; Toledo, 1598) with its notorious promulgation of tyrannicide challenged Vernulaeus to engage with that uncomfortable topic. The structure and scope of the Institutiones politicae indicated that Vernulaeus intended to align his work with the practical compendia of Lipsius and Contzen. He purposely imitated the breadth of Lipsius's Politicorum sive civilis doctrinae libri sex (Six Books of Politics or Political Instruction, 1589 ) by restating in varying degrees of detail Lipsius's views about the origins of civil society, the advantages of monarchy, the moral qualities that the prince and his court should possess and promote, the importance of taxation, and the organization and use of a modern standing army. ${ }^{42}$ For topics that

Philip. Dormalii, 1626). All of these works were reprinted, and in the 1640 s, each work appeared with extensive quotations from Vernulaeus's reading in political and moral theory. See especially the 1647 edition of the Institutionum politicarum libri IV, Nunc primum testimoniis, authoritatibus, exemplis et documentis, quae instar commentariorum sunt adornati (Louvanii: Ioannem Vryenborch, 1647).

42 Justus Lipsius, Politica: Six Books of Politics or Political Instruction (Politicorum sive civilis doctrina libri VI), ed. and transl. Jan Waszink (Assen: Royal Van Gorcum, 2004) Bibliotheca latinitatis novae, 5. On the relationship between Lipsius's political writings and Vernulaeus's Institutiones politicae, see Erik de Bom, Geleerden en politiek: De politieke ideeën van Justus Lipsius in de vroegmoderne Nederlanden (Hilversum: Verloren, 2011), pp. 308-328. Generally Vernulaeus incorporated into the first two books of the Institutiones politicae Lipsius's ideas in Politica, Books I-III about the origin of the state, the preference for monarchy, and the virtues the ruler and his counselors must possess. In his Book III, Ver- 
Lipsius omitted or for clarification of Lipsian opinions that appeared to clash with Catholic orthodoxy, Vernulaeus turned to the Politicorum libri decem (Ten Books of Politics, 1621) of Adam Contzen, the confessor of Maximilian of Bavaria. ${ }^{43}$ From that work, Vernulaeus derived his opinions about the independence of the Catholic clergy from political control, and the necessity for ecclesiastics to possess both wealth and secular power. In keeping with the medieval view of the social hierarchy, Vernulaeus not only accorded clerics the highest rank, but even suggested that they, because of their celibate state, made the best political administrators and rulers. He further followed Contzen in emphasizing the importance of state-administered education in order to control the potential growth of heresy in Catholic lands. ${ }^{44}$ But Vernulaeus did not always adhere to the Jesuit's opinions. On the ticklish question, especially in the Low Countries, whether private dissenters from a state's religion (the so-called 'quieti') should be permitted, Vernulaeus agreed with Lipsius's tolerant views but with the caveat that such citizens might one day endanger the security of the Catholic prince. ${ }^{45}$ Similarly, Vernulaeus differed from Contzen about the

nulaeus devotes much more space than Lipsius to the relationship between the Church and the State, and the duties of the prince to the Catholic Church. In contrast, in Books III, IV, and $v$ of Politica, Lipsius analyzes in great detail the different types of prudence including the concept of mixed prudence (prudentia mixta), or the careful use of deceit in governance, a term that Vernulaeus does not adopt though he shares Lipsius's belief that some secrecy and deception is necessary to govern well. Vernulaeus discusses taxation in III.5 following Lipsius, IV.3.5-11.

Adam Contzen, Politicorum librix (Moguntiae: sumptibus Joannis Kinckii, 1621). On Contzen, see Ernst-Albert Seils, Die Staatslehre des Jesuiten Adam Contzen (Lübeck: Matthiesen, 1968), and Robert Bireley, The Counter-Reformation Prince: Anti-Machiavellianism or Catholic Statecraft in Early Modern Europe (Chapel Hill: University of North Carolina Press, 1990), pp. 136-161.

44 Contzen discusses the importance of education in Book IV and the key role of the clergy in the administration of the state and church in Book VI of his Politicorum, librix.

45 Compare Lipsius, Politica, IV.4 (expurgated version, 1596) with Vernulaeus, Institutiones politicae, pp. 96-97. Lipsius IV.4 is one of the most disputed sections of the Politica. In the first edition (1589), Lipsius appeared to argue for freedom of conscience and allowed for the possibility that quiet dissenters might gently be persuaded to reform. The revisions of the Politica of 1596, 1599, and 1604, undertaken in response to the Vatican censors who had placed the Politica on the Index librorum prohibitorum still allow for quiet dissension but warned that private heretics should be watched carefully and prosecuted if necessary. Vernulaeus may have known both versions of Lipsius's work, but as a loyal Catholic, he followed the argument of the later expurgated version. See Waszink's detailed explanation 
use of deception (simulatio) in political matters and shared Lipsius's belief that a minor deceit ('fraus levis') was advisable in dealing with rebellious citizens and in upholding the secrecy of private councils. ${ }^{46}$

Although Vernulaeus's originality as a political thinker was limited, he differed markedly from his sources and even contemporary political writing such as Carolus Scribanius's Politico-Christianus (1624) in the manner in which he presented his ideas. Whereas Lipsius and Contzen had addressed their political books to aristocratic rulers-Lipsius boldly directed his treatise to all 'imperatores, reges, et principes' ('emperors, kings, and princes'), and Contzen dedicated his treatise to the Holy Roman Emperor Ferdinand II - Vernulaeus composed his study exclusively for student readers. ${ }^{47}$ For this reason, he dispensed with the learned citations from Greco-Roman and patristic writers that had characterized Lipsius's work, and perhaps even obscured his actual views, and with the even longer excerpts from Scripture and the ancients in Contzen so as to produce a school text whose brevity and perspicuity would capture his students' attention: 'I have looked towards utility and action; therefore I have omitted whatever does not pertain to these two. I have not taught about what has happened in the past, but what is happening and what could happen. I wanted to write something of use, not simply to fill up lots of pages, Indeed great knowledge is not not always found in huge volumes'. ('In Usum et Actionem respexi, ideoque quae huc non faciebant, omisi; nec quae olim facta, sed quae fiunt, aut fieri possunt docui. Prodesse enim volui, non chartas tantum implere. Neque sane in magnis voluminibus magna semper Scientia est.') ${ }^{48}$ Vernulaeus did, of course, possess an encyclopedic knowledge of previous political writing from Aristotle to the Jesuits, and in the subsequent 1647 Louvain edition of the Institutiones politicae he appended lengthy testimonia from this tradition to support his arguments. But in his original conception of the treatise, Vernulaeus emphasized its practical utility over its philological and scholastic roots. He took pains to present conflicting opinions about controversial issues such as the legitimacy of tyrannicide, or the necessity of a single state religion so that his students would be well equipped to debate intelligently about these problems. The stylistic significance of Vernulaeus's treatise lay in its reduction

of the controversy concerning IV.4 in the introduction to his edition of Lipsius's Politica, pp. 180-182. Seils overstates Vernulaeus's reliance on Contzen in this regard: Seils, Die Staatslehre, p. 215 .

46 Vernulaeus Institutiones politicae, p. 154; pp. 16o-165. Seils aligns Vernulaeus too closely with Contzen in the prudentia discussion: Seils, Die Staatslehre, p. 218.

47 Lipsius, Politica, pp. 226-229.

48 Vernulaeus, Institutiones politicae, sig. 7 . 
of contemporary political theory into an educational handbook without sacrificing the complexity of the original ideas. This same concern for a clear and effective form of political instruction informed the composition of Vernulaeus's historical dramas, and he adapted the existing Christian Senecan tradition of contemporary neo-Latin tragedy to his own pedagogical ends. Just as Lipsius had illustrated many of the political ideas described in his Politica in his subsequent historical collection Monita et exempla politica (Political Warnings and Examples, 1605), so too did Vernulaeus use the Louvain stage to represent both positive and negative examples of ideal political behavior described in his Institutiones politicae. ${ }^{49}$

Vernualeus was well aware of the disrepute into which the concept of a politicus had fallen because of the amorality ascribed to such behavior by the followers of Machiavelli. In contrast, he extolled the ideal politician as the 'good man skilled at governing' ('vir bonus regendi peritus'), a practical twist on the elder Cato's oratorical ideal of the 'good man skilled at speaking' ('vir bonus dicendi peritus') that was later echoed by Cicero, Seneca, and Quintilian. Vernulaeus further observes that the Christian statesman will possess 'a prudent mind, experienced judgment, and an eloquent way of speaking' ('pectoris prudentiam, consilii maturitatem, sermonis facundiam') and be a person 'who leads a good life, has a sincere faith, is always constant and courageous; who looks after everyone well, and who sets for himself the well-being of the people as the highest law' ('vita bonus, fide sincerus, semper constans, intrepidus, omnibus bene consulens, et salutem populi supremam sibi legem proponens'). ${ }^{50}$ The exemplary politicus will be knowledgeable about the law, pious and god-fearing, deeply familiar with history, and endowed with exceptional ability to act justly and prudently. Indeed, following Lipsius's revision of Machiavelli, Vernulaeus further argued that the successful statesman must possess prudence (prudentia) perhaps to an even greater degree than other virtues, for without prudentia, no ruler can effectively govern a state. ${ }^{51}$ Since statesmen are not born but

49 In the opening chapter of his Monita et exempla politica, Lipsius portrays himself engaged in a dialogue with his audience (auditor) who encourages him to finish the task he begun in his Politica by providing historical examples for readers to follow of the political ideas in the earlier work. Lipsius agrees, adding that warnings (monita) are also necessary for providing possible courses of action for future statesmen. Justus Lipsius, Monita et exempla politica qui virtutes et vitia principum spectant (1605; Amsterdami: apud Ioannem Blaeuw, 1668), pp. 7-10.

5o Vernulaeus, Institutiones politicae, pp. 7-8.

$5^{1}$ Vernulaeus, Institutiones politicae, pp. 144-147. Vernulaeus also writes about the characteristics of prudentia in his Institutiones morales, III.2, pp. 202-226. 
shaped through education, study, and experience to assume ever greater roles of political responsibility, he charges the preceptors of future statesmen with the essential task of ensuring the sound governance of the state. In his nuanced characterizations of rulers in extremis, Vernulaeus envisions historical drama as the visual manifestation of prudentia, and the Habsburgs as the contemporary exempla of his prudentia ideal.

\section{The Tragedy of Prudentia and the Limits of the Christianus Politicus}

Vernulaeus's tragedies are replete with contumacious rulers such as Theodoricus and Levigildus whose reprehensible behavior is repeatedly called into question by loyal counselors and the ubiquitous senex. Though almost exclusively focused on monarchs whose anger and lust had reduced them to tyrants incapable of emotional control, Vernulaeus complicates these unidimensional characterizations in many of his works. His Conradinus (1628) chronicling the downfall of the last scion of the Hohenstaufens in the mid-thirteeenth century presents a wide range of political activity exemplifying the centrality of prudentia. ${ }^{52}$ Having learned of Charles of Anjou's invasion of imperial lands in southern Italy, the youthful Conradin, eager to defend his inheritance, led an army of German nobles against the invader only to suffer a humiliating defeat in their first encounter. After a failed attempt to flee by sea, Conradin was captured, tried, and executed for his challenge to Charles's authority. Clearly Conradin's failed campaign against Charles of Anjou was a classic example of the prince's lack of prudentia. What makes Conradinus especially interesting, however, is the sophisticated manner in which Vernulaeus presented his case. First, he underscores the illegality of Charles of Anjou's seizure of Hohenstaufen territory. In this play, Charles is portrayed as the predatory tyrant who not only terrorizes his new Italian subjects into submission, but also later takes great pleasure in ordering the public execution of Conradin. In contrast to Charles's immorality, Vernulaeus juxtaposed the rashness of the politically

$5^{2}$ Nicolaus Vernulaeus, Conradinus et Crispus, tragoediae (Lovanii: apud Ioannem Oliverium, 1628), sig. ${ }^{* * *}$ iiii. Vernulaeus writes in his dedicatory letter to Albertus Hugonus Odonellus that he was drawn to Conradin and Crispus as exempla of noble forbearance when subjected to the vicissitudes of Fortuna: 'exhibuerunt ambo fato suo: instabilitatis Fortunae exemplum et fortitudine sua invicti animi documentum dederunt'. The ubiquitous presence of the senex, however, ensures that his student audiences also derive both political and moral lessons from the historical material. 
inexperienced Hohenstaufen prince. To be sure, he presented Conradin's eventual death as a political martyrdom, but he also took pains to demonstrate that Conradin's imprudent actions were responsible for his demise. He drew parallels between Charles and Conradin by characterizing them both as ambitious, self-seeking rulers who rely exclusively on the whimsy of Fortuna to determine their respective political futures. Luck alone, rather than an exceptional ability at statecraft, accorded Charles his victory over the young prince. Conradin, however, was defeated by fortune because of his inability to control his emotions and govern prudently.

In light of Vernulaeus's remarks in the Institutiones politicae, Conradin acted unwisely in several respects: his placed his own quest for glory above the best interests of the state; he failed to consider the consequences that would befall his kingdom should he, as the sole remaining heir, perish; he conducted a just war not to conclude a hasty peace but to acquire personal renown; he placed himself in unnecessary danger by leading his troops into battle, and once defeated, he immediately fled in despair despite the entreaties of his generals to continue the campaign while they still had the resources. ${ }^{53}$ Through this textbook example of the dangers of political ignorance, Vernulaeus encourages his viewers to acquire prudentia so that they could effectively counter the injustices with which Fortuna would inevitably burden them.

Political prudence also manifested itself in the ruler's commitment to secure internal stability and peace by upholding the one true religion, Roman Catholicism. In his Institutiones politicae, Vernulaeus had argued that if a king employed all his civil authority to protect Rome, then God would prevent any misfortune from befalling his land. ${ }^{54}$ Vernulaeus was, however, politically astute enough to perceive the difficulties of maintaining such a state in the modern world: both kings and Catholic clergy could easily err and fall from divine favor. He therefore devised a system whereby the Church and secular government could work together to realize the common good. The clergy were entrusted with ensuring that the Catholic state religion never suffer from any moral weaknesses that could be imputed to them or to the princes who were obliged to support them. Similarly, princes were charged with the responsibility of preventing prince-bishops and other clerical rulers from being seduced by the worldly wealth and power that they wielded as statesmen. Just as the clergy

53 Cf. Vernulaeus, Institutiones politicae, p. 531 (on the necessity to wage war to ensure peace); p. 549 (on the need for princes to protect themselves on the battlefield); p. $5^{89}$ (on the avoidance of despair after suffering a military defeat).

Vernulaeus, Institutiones politicae, pp. 93-95. 
oversaw a prince's allegiance to Rome, so did the Catholic prince guard against corruption among the clergy. 55

In his dramas of the late 1620s, Vernulaeus proposed the Habsburg rulers of Spain and the Holy Roman Empire as the embodiment of this ideal coexistence of Church and state. This allegiance was especially evident in his 1626 tragedy Ottocarus, on the rebellion of Ottokar of Bohemia against Rudolf I, the first Habsburg emperor. Here Vernulaeus established the Habsburgs as contemporary models of political prudence and warned their enemies of the folly of disputing their divinely ordained mandate to govern Catholic Europe. ${ }^{56} \mathrm{He}$ illustrates this point by attributing the characteristics of the ideal Catholic prince to Rudolf of Habsburg. The emperor is shown to work tirelessly for the preservation of peace by cultivating the love of his people, defending the Church, and waging a just war to ensure the safety of his subjects. He never acts without consulting the other princes of the realm, and he employs a mild, but politically prudent deception to force the rebel Ottokar to desist from war and acknowledge his authority. In contrast, Ottokar possesses all the familiar qualities of a tyrant: ambition, cruelty, susceptibility to flattery, and a vain belief in Fortune's favor, faults that Vernulaeus had criticized earlier in his political writings.

Such lessons are obvious to any careful reader of the drama and Vernulaeus's political works. But the Ottocarus also had another less conspicuous purpose: the legitimization of the Habsburg rule of the Low Countries. The rebellion of Ottokar of Bohemia against Rudolf of Habsburg was chosen as a dramatic subject to warn those contemplating or engaged in a rebellion against the Habsburgs, a dynasty whose triumphs fated them to arouse the envy of other less successful families, that such actions only lead to defeat and the further expansion and consolidation of Habsburg power. ${ }^{57}$ This message certainly struck a chord in the early 1620 , for the Dutch were assailed and overwhelmed on several fronts by the Spanish Habsburgs under Vernulaeus's favorite gen-

\footnotetext{
55 Vernulaeus, Institutiones politicae, pp. 334-341; 359-362.

$5^{6}$ Vernulaeus writes more expansively about the political function of tragedy in the dedicatory letter to Ottocarus than he does elsewhere. Building on the canonical definition of tragedy as the representation of the mutability of fortune and the downfall of kings, Vernulaeus observes that tragedy consequently is suited to impart instruction to rulers about the best way to avoid disaster. Tragedies are mirrors of kingship and educate statesmen in the virtues all successful rulers must possess: moderation, self-discipline, mercy, and prudence, for tragedy is, above all, the 'magistra prudentiae' ('teacher of prudence'). Vernulaeus, Ottocarus, sig. ${ }^{*} 2^{\mathrm{v}-}{ }^{*} 3$. 
eral Ambrogio Spinola. ${ }^{58}$ The Rudolf-Ottokar relationship also recalled the recent controversy between Frederick of the Palatinate, the luckless Protestant king of Bohemia in 1619-1620, and the Holy Roman Habsburg emperor Ferdinand II. Vernulaeus himself drew these connections in his dedicatory letter to the 'prudent and eloquent' Joannes Carolus, noting that both Rudolf and Ferdinand 'found the imperial throne beset all around by armed men; they could then show themselves to be eminently worthy of the imperial majesty by definitely triumphing over the rebels against the imperial eagle' ('[ambo] enim circumseptum armis imperii solium invenerunt, ut dignissimos se primae majestatis throno ostenderent, qui tam fideliter de Caesareae Aquilae Rebellibus triumpharent'). ${ }^{59} \mathrm{Just}$ as Ottokar perished because of his refusal to submit to Rudolf, so too was Frederick crushed by a superior Catholic army in 1620 because he had challenged Ferdinand's authority.

In the Ottocarus, the political lessons seemed remarkably clear; indeed Vernulaeus's pedagogical purpose would have been thwarted had his message appeared obscure. But the apparently unproblematic use of tragedy for political instruction does not permeate all of Vernulaeus's plays. His Counter-Reformation political ideas may explain his fascination with Church-state relations, but they do not provide much insight about the complex, and even contradictory, manner in which the secular and clerical humanist statesmen, all bent on maintaining their government's loyalty to Rome, are often portrayed in the dramas.

To clarify this point, let us consider the example of Vernulaeus's tragedy, Henricus octavus seu schisma Anglicanum (Henry viII or the English Schism; 1624), an unabashedly Roman Catholic representation of the conflict between Sir Thomas More and Henry viII. ${ }^{60}$ Not surprisingly, Vernulaeus paints an obviously partisan view of the conflict: he simplifies the political and ecclesiastical complexity of the debate, and reduces the crisis to a bedroom soap opera with Henry burning for the fulfillment of his carnal desires, Anne Boleyn's coy refusal

$5^{8}$ Jonathan I. Israel, The Dutch Republic, its Rise, Greatness and Fall, 1477-1806 (Oxford: Oxford University Press, 1995), pp. 478-485.

59 Vernulaeus, Ottocarus, sig. * 5 . Vernulaeus deemed Joannes Carolus an especially worthy recipient of this play, for Carolus's political service to the Prince Archbishop of Mainz, and to both the Austrian and Spanish Habsburgs was much admired even by the emperor and the king of Spain for his ability to resolve difficult negotiations with other governments, both Catholic and Protestant. Vernulaeus attributes such skills to Carolus's mastery of both eloquence and prudence: Ottocarus, sig. *6.

6o Nicolaus Vernulaeus, Henricus octavus seu schisma Anglicanum (Lovanii: typis Philippi Dormalii, 1624). 
until the divorce from Catharine of Aragon, and Thomas More's constant, but fruitless, reproach of his perennially overheated king. ${ }^{61}$

In light of Vernulaeus's program of political education, and the political sophistication evidenced by his students in their school orations, such a naive approach to a still contemporary problem, Church-state relations, seems remarkably jejune. But there is an even more arresting problem: Vernulaeus's schoolboys were clearly enjoined to admire the piety of Thomas More, his Stoic withdrawal from the political arena, and his courageous martyrdom. In an historical drama purportedly written to impart practical political instruction, one paradoxically finds the ideal Christian humanist advisor upbraiding the king for his immorality, but failing to prevent the lapse of the king and the state into tyranny and heresy. Such an outcome is troubling in light of Vernulaeus's political mission, for this consequence calls into the question the effectiveness of the Christian political ethic to ensure good government and social stability. To be sure, the triumph of tyranny on earth is shown to be temporary, for Henry, along with the tyrants of Vernulaeus's other tragedies, goes quickly insane, or is dragged into hell by devils - a pedagogical device especially favored by the Jesuits. But the Christianus politicus, goes to the scaffold. How can this disparity between the private, spiritual triumph of humanist martyrs, such as Thomas More, and their political failure be explained? What historical circumstances have brought Vernulaeus, the leading humanist political dramatist of his time, to such a melancholy conclusion?

I can only suggest a brief answer here, but the complexity of this issue demonstrates the way in which disharmonies between the didactic program of the Latin dramatists and the plays themselves can uncover deep-seated problems in late humanism. Vernulaeus's paradoxical representation of the Christian statesman was not unique to his historical situation. At other humanist schools with aggressive political curricula in the early seventeenth century, such as the academy at Strasbourg, arguments were being made with similar enthusiasm for an ideal Christian state in which the well-trained students of the humanist gymnasia will guarantee a stable and peaceful government as long as they are permitted to play major roles in the administration of the court. ${ }^{62}$ This

61 Henry's passion for Anne Boleyn recalls the uncontrollable adolescent lust that afflicts enamored young men in Terentian comedy. Vernulaeus's female characters are often represented as alluring distractions who mislead accomplished rulers into imprudent behavior: Ottocarus's wife Kunegundis is especially blamed for inciting her husband's revolt against Rudolf (Ottocarus, sig. *5). Vernulaeus discusses the perils of lust for statesmen in his Institutiones politicae, p. 141.

Parente, 'Tragoedia politica', pp. 5-9. 
case was generally made by means of negative exempla: the plays demonstrated the chaos that ensued upon the condemnation of the humanist courtiers/ administrators. But these same humanist courtiers were, like Thomas More, often shown to be outwitted by other amoral court advisors whose clever manipulation of the generally weak monarch ensures them the greatest power and influence. The execution of the Christian humanist, though a spiritual victory, reveals a growing alienation between the political instruction in the schools and the harsh political and religious realities of the early modern state. When viewed against the shortcomings of the humanist political program, the glorious martyrdom of the Christian politician must be seen as an idealistic attempt to gloss over the inability of the Christian moral-philosophical system to serve as a political tool, and to perpetuate the self-serving argument that humanist-trained politicians remain the best statesmen (and even better martyrs), especially when their superior political advice has failed. This inability to separate an idealistic moral philosophy from political reality paradoxically ensured the growing marginalization of the humanist scholar in the seventeenth century from the institutions of power they so eagerly yearned to serve.

Not all of Vernulaeus's works betray such a damning view of the future of Christian. i.e., Catholic, political action: there are ideal politicians such as Rudolf of Habsburg in the Ottocarus, who seem exceedingly exemplary-as do all Habsburgs in Vernulaeus's world, but such moments are rare. Instead Vernulaeus's schoolboys witnessed, and acted out, the brashness of Conradin von Hohenstaufen, the murders of Lambert of Maastricht, Stanislaus of Cracow, Thomas Becket, and the execution of Jeanne d'Arc. To be sure, divine choruses of angels and saints reassured the audiences of the temporary nature of the triumphs of the Machiavellian enemies of Rome, and the ultimate victory of Divine Justice, but in the face of the harsh political realities of the early seventeenth century, such sentiments are merely consolatory utopian projections designed to thwart the inevitable chaos of history. Through his vivid representation of the increasing ineffectiveness of the Christian humanist politician at courts in which law and power were regularly abused by arrogant and talentless rulers, Vernulaeus paradoxically transformed the traditional humanist view of history as a compendium of moral exempla into a melancholic lamentation on the mutability of political life —or, to speak with Walter Benjamin ${ }^{63}$ —of the Trauerspiel of human existence and the concomitant rift between Christian man and an increasingly secularized world.

63 Walter Benjamin, Ursprung des deutschen Trauerspiels (Frankfurt am Main: Suhrkamp, 1972) Suhrkamp Taschenbücher, 69, pp. 51-54. 
Vernulaeus's turn to historical and political drama was motivated primarily by his desire to prepare the noble students in his charge to assume positions of secular and ecclesiastical leadership in an age of near-perpetual war. He refrained from naïve representations of Christian morality to incorporate the ideas he garnered from his wide reading in sixteenth- and early seventeenthcentury political theory into his characterizations of rulers, bishops, generals, and counselors, and measured accordingly their respective abilities to govern the early modern state. He countered the efflorescence of historical and political drama emanating from the Protestant North, in both Latin and Dutch, and in some cases problematized the same issues (e.g., the legitimacy of tyrannicide; the relationship between church and state); he adapted repertoire from his Jesuit contemporaries and reshaped it to present a broader series of tableaux of the administrative problems that the new Christian statesmen were likely to encounter, and he brought new exempla of political behavior to the stage. As a gifted educator, he remained optimistic about the virtue, stability, and peace that could be celebrated and maintained through effective governance, but he also recognized that despite their best efforts, Christian politicians were overtaken frequently by misfortune or other unforeseen events. In such dire circumstances when all other options were foreclosed, the irreproachable manner in which the Christian statesman confronted the inevitable was more significant than expedient, morally reprehensible conduct. Vernulaeus's historical tragedies thus exemplified both the efficaciousness of prudent political action but also the limitations of a Christian statesman's ability to effect lasting change in an increasingly uncertain world.

\section{Further Reading}

Note: There is little secondary literature on Vernulaeus's works, especially his dramas. The following readings will provide further information about his writings and the broader literary and historical context in which he worked. See also note 3 above.

Bireley, Robert, The Counter-Reformation Prince: Anti-Machiavellianism or Catholic Statecraft in Early Modern Europe (Chapel Hill: University of North Carolina Press, 1990), pp. 136-161.

Bloemendal, Jan, 'Neo-Latin Drama in the Low Countries', in Jan Bloemendal and Howard B. Norland (eds.), Neo-Latin Drama and Theatre in Early Modern Europe (Leiden and Boston: Brill, 2013) Drama and Theatre in Early Modern Europe, 3, pp. $293-364$. 
Groenland, Juliette A., 'Playing to the Public, Playing with Opinion: Latin and Vernacular Dutch History Drama by Heinsius and Duym', in Jan Bloemendal, Arjan van Dixhoorn and Elsa Strietman (eds.), Literary Cultures and Public Opinion in the Low Countries, 1450-1650 (Leiden and Boston: Brill, 2011) Brill's Studies in Intellectual History, 197, pp. 127-150.

De Bom, Erik, Geleerden en politiek: De politieke ideeën van Justus Lipsius in de vroegmoderne Nederlanden (Hilversum: Verloren, 2011), pp. 308-328.

De Puydt, Joost, 'Nicolaus Vernulaeus', in Jan Bloemendal and Chris Heesakkers (eds.), Bio-bibliografie van Nederlandse humanisten, Digital Web Center for the History of Science in the Low Countries / Huygens Institute, 2009, http://www.dwc.knaw.nl/.

Duits, Henk, Van Bartholomeusnacht tot Bataafse opstand: Studies over de relatie tussen politiek en toneel in het midden van de zeventiende eeuw (Hilversum: Verloren, 1990).

Graupe, Katharina, Oratio historica —Reden über Geschichte: Untersuchungen zur praktischen Rhetorik während des spanisch-niederländischen Konfliktes im 16. und 17. Jahrhundert (Berlin and Boston: De Gruyter, 2012), Frühe Neuzeit, 156, pp. 303-369.

Klecker, Elisabeth, 'König Ottokars Glück und Ende in lateinischer Sprache', Jahrbuch der Grillparzer Gesellschaft, 3. Folge, Bd. 21 (2003-2006), 65-107.

Niefanger, Dirk, Geschichtsdrama der frühen Neuzeit 1495-1773 (Tübingen, Niemeyer, 2005).

Noak, Bettina, Politische Auffassungen im niederländischen Drama des 17. Jahrhunderts (Münster: Waxmann, 2002).

Parente, James A., Jr., 'Tragoedia Politica: Strasbourg School Drama and the Early Modern State', Colloquia Germanica 29/1 (1996), 1-11.

Parleiter, Veronika Coroleu, 'Nicolaus Vernulaeus' Darstellung der Habsburger: Apologia, Virtutes und Historia Austriaca mit einem Exkurs über die Methodus legendi historias', Humanistica Lovaniensia 56 (2007), 233-270.

Schuster, Louis A. (ed. and transl.), Henry VIII: A Neo-Latin Drama by Nicolaus Vernulaeus (Austin: University of Texas Press, 1964).

Szarota, Elida Maria, Geschichte, Politik und Gesellschaft im Drama des 17. Jahrhunderts (Berne: Francke, 1976). 